\title{
QUEEN'S
UNIVERSITY
BELFAST
}

\section{We need to talk about managerialism: On the Importance of values dialogue and renewal within Catholic schools}

Donnelly, C., \& McKevitt, J. (2016). We need to talk about managerialism: On the Importance of values dialogue and renewal within Catholic schools. Policy Futures in Education, 14(8), 1078-1090.

https://doi.org/10.1177/1478210316679037

Published in:

Policy Futures in Education

Document Version:

Peer reviewed version

Queen's University Belfast - Research Portal:

Link to publication record in Queen's University Belfast Research Portal

Publisher rights

(c) 2016 The Authors

\section{General rights}

Copyright for the publications made accessible via the Queen's University Belfast Research Portal is retained by the author(s) and / or other copyright owners and it is a condition of accessing these publications that users recognise and abide by the legal requirements associated with these rights.

Take down policy

The Research Portal is Queen's institutional repository that provides access to Queen's research output. Every effort has been made to ensure that content in the Research Portal does not infringe any person's rights, or applicable UK laws. If you discover content in the Research Portal that you believe breaches copyright or violates any law, please contact openaccess@qub.ac.uk. 


\title{
We need to talk about managerialism: On the Importance of values dialogue and renewal within Catholic schools.
}

\author{
Caitlin Donnelly and Jeanette McKevitt
}

\begin{abstract}
.
Whilst reports of value tensions between new managerialism and Catholic education have emerged as a key theme in the academic literature there remains little empirical understanding of how teachers negotiate these complex terrains in Catholic schools. Drawing on qualitative data from teachers in two Catholic post-primary schools in Northern Ireland, this paper sought to explore how Catholic teachers developed a distinctively Catholic ethos against a culture of 'creeping managerialism'. The paper has shown that despite the predominance of managerial practices, tensions between managerialist values and the 'Catholic ethos' did not emerge in either context: in one school managerialism permeated the school and the Catholic ethos was constructed within this context. In the other school a staff process of spiritual renewal had consolidated a commitment to the Catholic faith and social inclusion. It was argued that the dialogical engagement around Catholic values may help Catholic schools defend against the harsher manifestations of managerialism without compromising the pupils' capacity to realise their academic potential
\end{abstract}

\section{$\underline{\text { Introduction }}$}

New managerialism is commonly regarded as a solution to public sector profligacy and inefficiency. Initiated in the United Kingdom under the Thatcher administration in the 1980s, the focus was on the importation of business models of management to the public services with the intention of increasing profitability, efficiency and accountability. Whilst the effects of new managerialism on schools were heavily critiqued in educational literature in the 1990s (Ball et al, 1994; Considine, 1988; Gewirtz et al, 1993; Jeffrey and Woods, 1998; McLaughlin, 1994;) the detractors have been notably silent in recent years. This has led Ball (2003) to argue that the well-worn mantra of 'There Is No Alternative' rehearsed frequently by Thatcher, has been so successful that society has begun to imbibe the central tenets of new managerialism within the public sector and uncritically accept its application to public goods such as education. Yet the austerity measures taken by the Conservative led coalition government since 2008 have stimulated a renewed interest and critique of managerialism. Social and political commentators are once again highlighting the limitations of this approach and questioning the 'punitive' neo--liberal values that seem to be embedded within it. A recent article in the Guardian for example de-cries the individualistic values that lie at the heart of the neo-liberal agenda:

There are constant laments about the so-called loss of norms and values in our culture. Yet our norms and values make up an integral and essential part of our identity. So they cannot be lost, only changed. And that is precisely what has happened: a changed economy reflects changed ethics and brings about changed identity. The current economic system is bringing out the worst in us. (Verhaeghe ${ }_{2}$ Guardian September 29 2014)

The academic literature has identified similar issues particularly around the norms and values that are perpetuated within educational contexts. Gewirtz et al (1993) for example suggests that the criteria and mechanisms of success as defined by managerialism, are generally at odds with traditional educational values and therefore likely to cause a 'values drift' within schools whilst Pring (1996), writing specifically about Catholic education, argues that the neo liberal market values which underpin new managerialism are 
'antithetical' to those values which are critical to Catholicism and Catholic education. However despite these concerns there remains a significant gap in our empirical understanding of Catholic education and the ways in which the values it upholds are juxtaposed against the ideals espoused by managerialism (Grace, 2002). The purpose of this paper is therefore to draw on qualitative evidence from two Catholic post-primary schools in NI to explore the interaction between Catholic educational values and the values inherent within the new managerialist philosophy. The paper will begin by defining new managerialism, delineating the neoliberal values which underpin it and demonstrating why these values are likely to clash with values within Catholic schools. Having rationalised the need for empirical research in this area, the paper will outline the methods of the qualitative study and the conclusions reached from the data analysis.

\section{New managerialism and Catholic Education: A Value Clash}

Reference to performance targets, business plans, choice, markets competition and accountability, all manifestations of new managerialism within education, sound like positive innovations which can only serve to increase the standard of educational provision within schools and the efficiency of the education system. The values that underpin these processes are inexorably entwined with and informed by neo-liberal ideology. As a synthesis of classical liberal doctrines, neoclassical economics and private management theories, neoliberalism is a political ideology underpinned by a market conception of the individual as a selfish, selfmaximising, 'consumer'- 'homo economicus' (Olssen et al, 2004:137). In this sense the neoliberal ideology is framed by a reductivist conception of human life as essentially economic and solvable by the panacea of 'the market' (Lauder, et al., 1999). Neo- liberalism then, the bedrock of new managerialism, is underpinned by a business model of entrepreneurship. It champions individualism and competition and holds a narrow, pessimistic view of human nature, of society and of the aims and purposes of education. Under new managerialism the pupil/parent is reconfigured as a 'consumer' whose value lies in academic performance. Schools and teachers become 'service providers' and education is reduced to an instrumentalist, skills based service for the facilitation of economic growth (Lauder, Hughes et al., 1994). Schools as service providers accountable to customers are subject to increasing and pressurizing levels of monitoring and surveillance. Relationships between schools become competitive when each pupil represents a unit of income, and when schools are ranked for academic performance in unofficial league tables. When teaching and learning becomes 'transactional' (Lynch, 2013:5) the teacher pupil relationship is unrecognisably altered. The result is that teachers may '...find their values challenged or displaced... [amidst] a '...structural and individual schizophrenia of values and purposes' (Ball, 2003: 216), culminating in a 'values drift' within schools (Gewirtz et al., 1993: 239). Within the Northern Ireland context, Smith and Montgomery's (1997) study examining educators' perceptions of values in the context of the curriculum, hints at the existence of value tensions and dilemmas caused within schools as a result of New Managerial reform. Teachers expressed discomfort with the 'depersonalizing' concepts of 'marketing', 'accountability' and 'inputs and outputs' imported from the business world (Smith and Montgomery 1997:104) and the 'conceptual reframing' of the school system where 'everything moves up' and where teaching strategies are 'top down', pitched towards the more able pupils first and considering the less able as an afterthought (Smith and Montgomery, 1997: 105). Thus, whilst there are indications that educators in Northern Ireland may feel they are suspended between competing tensions as a result of new managerialism the literature has yet to build upon this insight with further research.

What does seem clear though is that these tensions are potentially heightened within the context of the Catholic school which is obliged by Church teaching to live out its Catholic mission yet equally required to maintain institutional survival in the marketplace. Grace (2002) for example argues that tensions are inevitable as the neoliberal paradigm seeks to remove the value of education as a public good and to subjugate the moral, social and pastoral aspects of it to managerialist imperatives for academic success. Pring 
(1996) similarly suggests that such objectives are deeply antithetical to the ethos, mission and purpose of Catholic education which is characterised by five regulative principles that include: education in the Catholic faith; a preference for the poor within the schools' admission criteria; the provision of a holistic and socially just education concerned with the formation of the whole person; an emphasis on the spiritual, moral, intellectual, physical and social development of pupils within a community context; and a belief that education is for the purposes of the common good, where the acquisition of knowledge and skills are a means and not an end (Grace 2002). Arguably the Catholic schools' educational vision as encapsulated above, is diametrically opposed to a new managerialist conception of the pupil as a customer and of education as a skills based service, bereft of any moral vision, It is within this context that Grace asks what becomes of the Catholic school's spiritual and holistic mission, its preference for the poor and its commitment to social justice, when new managerialism solely rewards the visible outcome of academic performance (Grace, 2002). The temptation is for Catholic schools to become selective in their admissions and deliberate in their exclusions; to reduce the number of pupils with additional needs and the resources allocated to them (Gewirtz et al., 1993). The temptation is to compete with neighbouring schools instead of acting in community and collaboration with them. The temptation is to reduce allocated space on the timetable for Religious Education and to make room for subjects that have more obvious economic and instrumental value in the market.

The ostensible dissonance in the values championed within Catholic education and those embedded within neo-liberal ideology, raise obvious yet largely under-researched questions around the balancing of these contrasting philosophical positions on the role of education within Catholic schools. Hence the purpose of this paper is to explore this issue by drawing on the views of Catholic educators in two post primary schools in Northern Ireland. Northern Ireland offers a useful site in which to conduct the research because although Catholic education has been prized by the Catholic community as a space in which to reproduce their Irish national culture and Catholic religious values which were traditionally under threat within the Northern Ireland state, it has also had to articulate and defend its position more vigorously than in other parts of the UK (McKeown and Clarke, 2006). Thus of all areas of the UK it might be argued that value tensions will be heightened in NI as the Catholic school has frequently been called upon to justify its very existence and is deeply conscious of the 'ethos' that it seeks to transmit.

\section{Methods}

\section{The Schools}

The study presents the results of a research project which explored managerialism in 2 Catholic post-primary schools in NI. The schools had several characteristics in common: both were approximately the same size: they each enrolled around 1000-1500 pupils; in addition they were located in areas of high deprivation and so the numbers of children with Free School Meals was higher than the average for schools in Northern Ireland. Despite the levels of economic deprivation it is perhaps significant that pupils in both schools performed well in national examinations and this was reflected in their position within the league tables, although it is important to note that pupils at St. Scholastica outperformed those in St Isidore. 1. The key difference in the schools was related to their location and the gender of the pupils: St Scholastica was situated in an urban area and was a girls' only school whilst St Isidore was mixed gender and located in a more rural area. The different location is relevant in so far as the more urban context seemed to have instilled in staff a greater consciousness of the educational market and inter-school competition.

${ }^{1}$ In the interests of anonymity, we are not able to reveal more specific details about the characteristics of the schools. 


\section{The Qualitative Approach}

Qualitative methods with their emphasis on meaning making and understanding the 'lived experience' of participants (Flick, 2013) seemed particularly apposite for this research. Firstly, there is as noted above, a dearth of empirical research in the field so the qualitative method allowed for the exploration and emergence of issues that may not yet have been delineated within the extant literature. Secondly and perhaps more importantly though, the qualitative methods allowed the researcher to capture the very real struggles which educators have in negotiating and making sense of the distinct value systems that are inherent within Catholic education and new managerialism.

\section{Data Collection}

Ethical approval was sought and granted for the data collection. The researchers wrote to the principal of each school and after an initial meeting it was agreed that the research could proceed. The initial phase of the research was concerned with analysing school documents: The School prospectus, website, online inspection reports and School development plan were reviewed before interviews took place. These allowed the researchers to become acquainted with the official pronouncements and the mission and ethos of each institution. Each Head was then interviewed and they also assisted in the selection of each of the remaining participants. A total of 20 interviewees [including the Heads] took part in the research. Semi-structured interviews were thus conducted with nine classroom teachers and the head in each school. Teachers were drawn from a range of disciplines and were employed in a variety of leadership positions throughout each school. Interviews ranged from forty-five minutes to two hours in duration and were recorded on a dictaphone and transcribed. The data was stored in NVivo 10 and analysed using thematic analysis.

\section{Researcher Reflexivity}

Both researchers are Catholic and were educated in Catholic schools in Northern Ireland. Whilst efforts were made to ensure impartiality, the values and prior experiences of the researchers no doubt exerted an influence on the data collection and its analysis. Although it is difficult to be definitive, there was an affinity between the interviewer and the participants that may have been more difficult to establish had we been perceived to be 'outsiders' to the Catholic community. Similarly the language, culture and ethos described by participants in each of the schools were familiar to us. Whilst this positioning as an 'insider' researcher has been described as a 'double edged sword' and it might have de-sensitised us to some of the embedded practices in Catholic education, we ultimately regarded it as a benefit as it allowed us to more easily access, appreciate and understand the experiences of participants (Mercer, 2007)

\section{The Data}

\section{Constructions of Catholic Education: Ritual and Praxis}

Initial questions sought to explore how participants constructed Catholic education within their school. Perhaps expectedly most participants referred to the ritualistic or liturgical aspects of Catholicism as a key distinguishing feature of their school. Frequent reference was thus made to the celebration of religious events or Church holidays and when asked to identify the differences between Catholic schools and state schools within Northern Ireland, participants were keen to emphasise the unique and positive emphasis on 'religiosity':

.....I suppose we are a denominational school we do have the liturgy and all of that and obviously the year is punctuated by the celebration of different events with regard to the academic calendar and the sporting calendar and the music and whatever. But it is also punctuated by certain religious 
events. Say for example this Sunday, October is the month of the Rosary so girls and staff will go on the rosary procession so that would be an example of it....(senior teacher St Scholastica)

I think obviously there is that element of worship and liturgical worship and that aspect of it. I suppose we have our leavers mass and our fifth year mass and our year eight so maybe the liturgical side [is different] ... (senior teacher, St Isidore)

So you know the ethos is transmitted visually, there are religious icons and iconography around the school so visually that is transmitted. Assemblies always start with a prayer, most registration groups start with a prayer... (St Scholastica)

We have a crucifix in each room having our prayer to St Isidore; having mass we have mass twice a week and the sacrament of reconciliation [senior teacher St Isidore]

Yet teachers also argued that Catholic education necessarily extended well beyond a routine deference to religious ceremony; interviews across both schools were replete with references to the social function of the school and participants argued that it was in their capacity to 'make a difference to pupil's lives' that they could ensure that a more socially just educational experience:

I think the social justice aspect of the mission is stronger now than in the 1970s (senior teacher, St Scholastica)

In terms of social justice ... I would say we are 8 maybe 9 out of 10. I am going to be honest I think that is what we do best. We do that best (Senior teacher, St Isidore)

Participants across both contexts related examples of their global and local charitable endeavours as evidence of their commitment to a just and equitable society and much time was spent articulating the value of such activity:

...us going out to families with hampers at Christmas for example, of subtly recognising a child who has a hole in their shoes and us being able to replace the shoes, maybe a child whose blazers too small for them, we can get them a new blazer (teacher St Isidore)

For the last four years we have had a group of staff and students going out to Zambia. And that would be the main fundraising efforts of the school. But this week we have had fund raising for Lepra which is a leprosy charity. St. Vincent de Paul is very, very big in my heart. There is a St. Vincent de Paul conference in the school. That would be a big thrust over the next month or so. (Principal St Scholastica)

Yet the extent of initial consensus around the importance of these activities in the schools seemed to belie a discord across the institutions around how the concept of social justice was conceptualised. For participants in St Isidore, social justice was inevitably and intrinscally related to social inclusion. Aside from its obvious role as a site for learning, interviews suggested that the school was also framed as a complex social space wherein the poor, deprived or marginalised could find social, emotional and, where required, financial support. Moreover, and unusually perhaps for a Catholic school, much was made of the school's role in attending to those who might find themselves excluded because of their sexuality. Thus the Head explained that it was in the school's concern to celebrate the gay community that best captured its commitment to social inclusion and social justice:

A student came in who had been a victim of a homophobic assault and the police weren't taking it seriously he assumed as a Catholic school you can't do anything for me, he said, because I know what 
Church teachings say... So I said but we have our inclusion policy and that. And he says, but that is only words on a page... He says it's about witness, it's about actions and there is more than me in this school who is gay. So I had a very good conversation with him, very positive and he was surprised that I was so disposed towards him. Over the next fortnight then, leading up to Halloween, another five fellas came into my office. And it was the same story. Sir I am gay but I am suicidal and I am selfharming and I don't know what to do because I have not told anybody. So it was in that context that the decision happened. I couldn't get that out of my Head because when we talk about male suicides and all of that stuff, self-harming and self-esteem and although our Church teaches that we show compassion to gay people and all the rest, it also teaches that they are intrinsically disordered. I am very proud of what we did... one of things about our church is that we reach out to marginalised people and that is what we did ... we are living out our witness as a Catholic school.

As is acknowledged, this interpretation of social justice places the school and its teachers in a dilemma. Balancing the needs of young people who are socially excluded and victimised because of their sexuality against the demands of local clerics who, according to the Head, determined such feelings to be 'disordered' inevitably created a dissonance between Church and school that the Head had argued placed him in a 'difficult position' with senior Church authorities. Yet the rationalisation for his approach was found in an overriding commitment to social inclusion and a compelling desire to create a welcoming atmosphere for children, even if this meant that there was a departure from the Church's doctrinal demands.

As was evident above, a commitment to social justice was also a key concern for teachers in St. Scholastica. However instead of seeking to engage with the personal and emotional struggles of those in need the teachers here argued that it was in their capacity to develop the academic potential of 'bright working class children' that best captured how they might promote social justice:

A preference for the poor is this school in a nutshell. What better provision for the poor than to equip them with a holistic education that arms them to go out into the world and to be able to take their place in the world? (Senior teacher St. Scholastica)

Social justice was not framed in terms of inclusion but rather the focus was on social elevation and education was regarded as a key vehicle for social mobility. Teachers were proud of the culture of academic achievement and the school was defined as a place wherein students, particularly those from more deprived backgrounds, could realise their academic potential. A variety of techniques were employed to ensure 'success': the school was open for over 12 hours per day and on Sundays during exam time and this was widely rehearsed in interviews as evidence of the commitment of staff to the pupils and an exemplification of the Catholic ethos in action:

Now when it comes to exam time one of the SMT myself included will operate that on a rotational basis Monday to Thursday until 9pm; and then the principal does it on a Sunday from 2-9 as well around exam times. That has become more and more popular over the years and certainly last year it was full every night until nine pm and on the Sunday too [senior teacher]

That children did not have home lives that were conducive to learning was articulated by several interviewees who were keen to present the school as acting in a compensatory capacity for parents who they argued could not equip pupils with the level of academic support that they required. The school was a place then where children could become acculturated to a context where academic achievement was privileged and scholarly activity applauded. The reference below to the school as a 'helicopter parent' seemed to neatly capture the culture of the school which was one where teachers engaged in extensive surveillance and monitoring to ensure that 'students conform [ed] with behavioural expectations associated with learning' (McFarlene, 2013:1). 
There are a lot of pupils coming here to this school who don't have an academic supportive environment at home, due to the nature of the area and due to the nature of their homes lives. However, we have created an ethos.... an ethos where the pupils want to achieve and where they want to go to university and study courses and take challenging courses and they want to improve themselves academically... (Teacher)

I suppose you have heard of helicopter parents? They tend to say that middleclass parents are hovercraft parents, they are always hovering round making sure that everything is put in place and I was that kind of parent. Because I had the wherewith all and the knowledge of all the pitfalls and I suppose I tend to think of us as a hovercraft school (Head teacher)

But whilst the concern to monitor pupils was obviously driven by laudable intentions, there are fears that such activities can prompt infantilisation amongst students by reducing academic autonomy and self-esteem (Rutherford, 2011). Indeed and of particular relevance to this school, excessive surveillance of pupil learning has been shown to have an especially negative effect on the performance and emotional state of girls from more deprived backgrounds. Reay (2006) for example refers to the 'hidden injuries of class' that are perpetuated through contemporary educational policies and she argues that increasing the academic regulation of children from working class backgrounds has adverse effects. Thus whilst she found that children were generally discomforted by testing, it was usually the 'working-class girls who expressed 'paranoid' fears about the Standard Attainment Tests. They were most likely to talk in terms of damage to the self as a consequence of contemporary testing regimes' (p300). Thus and somewhat paradoxically, the construction of social justice in the terms outlined above may lead to a loss of esteem, confidence and autonomy amongst the very children which the school sets out to support.

So far the data highlights contrasting constructions of Catholic education; each of the schools unquestioningly situate themselves within a distinctly Catholic religious philosophy yet their perspectives on social justice differs across the institutions. But how do teachers negotiate the values enshrined within Catholic education and managerialism across the different contexts?

\section{Managerialism and Catholic education: a clash of values?}

In St. Scholastica where the emphasis was unreservedly on academic success for the poor, there was, perhaps expectedly, little sense of competing value systems in the school; instead the rhetoric of new managerialism, permeated the lexicon and infused the practices that were championed by professionals. Interschool competition and the commodification of education were not lamented by teachers but instead were embraced and reflected upon as a positive, effective and an inherently 'normal' way to raise academic standards:

To what extent is your school led by its Catholic mission or the market conditions?

Your product has to be good. And your product has to be honest. So your ability to attract in the market has to be based on what you have to sell. And I do consider the St. Scholastica business and I make no apology for that... at the end of the day really unless you are trying to do your best you shouldn't be in the market .... (head teacher, St Scholastica)

Well everybody likes to be the best and to do the best but at the end of the day have to say with regard to our children here in this area they are very proud of the fact that they are doing so well. Sometimes people would have looked down on them.... So our pupils are tremendously proud of the 
fact that they are doing as well and that they are holding up against other areas. Parents have very high expectations...(head teacher, St Scholastica)

The positive reference to the educational 'product', the primacy of academic performance and the evident pride in becoming 'a market leader' [interview data] suggested that the essence of managerialism had become 'imbibed' much in the way that Ball (2003) predicts. Few tensions emerged between the value systems of Catholic education and managerialism because Catholic education had been constructed in a way that strongly coalesced with the fundamental tenets of managerialism: Framing the school as a site which allowed the poor access to an 'excellent academic education'; and ensuring that children's learning was highly regulated, fits neatly with managerialist notions of performativity, regulation and surveillance. Professionals absolved themselves of any fear that they may be preserving a model of education that was potentially damaging to pupils or importantly in contravention of their Catholic ethos; rather they argued that it was precisely through a selfless commitment to the 'excellent' education of impoverished pupils that they were simultaneously able to realise the aims of Catholic education whilst responding positively to the demands of achievement oriented, academically aspirant 'customers':

What do you think of league tables?

League tables matter a lot to parents... everybody likes to be the best but at the end of the day I have to say with regard to our children here in this area they are very proud of the fact that they are doing so well... (teacher St Scholastica)

This is very much an academically focused school but running alongside that the child is recognised as an individual; if the child is not recognised as an individual then the academic bit is not going to be right (teacher, St Scholastica)

Yet where participants in St. Scholastica seemed to have absorbed managerialism and created a positive rationale for pursuing it within the Catholic school, for those in St Isidore, the tenets of this ideology were regarded as largely detrimental to the emotional and spiritual growth of children and as Pring (1996) acknowledges, deeply antithetical to the Catholic ethos. A senior teacher drew sharp contrasts between the values that informed his own school and those that he perceived to prevail within schools which were 'market focused'. He argued that the emphasis on examination performance and academic success was excessive and fundamentally challenged the transmission of Catholic values:

It [managerialism] is ruthless and it is every single thing that a Catholic school is not. They are in the results business. They are results factories and when the league tables come out they are vying for top spot. And when you are vying for top spot you cease to be child centred and you become results centred. And the children become commodities on your way to achieving that. We are not a results factory. We believe that children should enjoy their lives. We want them to enjoy their lives here. So we are a completely different educational experience ....this is not a business this is a Catholic school. The children come first and we will do everything as long as it benefits the children. So it is running a business but the business is people. James Connolly I think said 'my business is revolution', our business as a Catholic school is transformation

Despite a recognition of the limitations of the 'business model' of education there was little evidence of the dilemmas and tensions that might be expected within a school that was so obviously shaped by and mindful of its Catholic mission. The reasons for this were difficult to disentangle through interview but for one of the participants the answer lay in an attempt made ten years ago to 'reimagine' the Catholic ethos of the school. This whole school program facilitated the questioning of the school's core Catholic values as well as the faith journeys of individual staff. Whilst one teacher explained that this process of 'spiritual renewal' had provoked 
considerable discomfort, it had strengthened the school's ability to retain its core Catholic value system through group conversation and dialogue. One significant consequence was that a deep consensus was found around the school's uniquely Catholic values:

One of the nice things we engaged in about ten years ago now ...we decided to go through a three year process called re-imagining the Catholic school. This was a staff exercise and we went through a catharsis, we talked about what spirituality meant to us. What was the role of the Catholic school? Where was Catholicism going to be in the school... And that took about three years. We did it on staff days maybe once in the first term maybe once in the second term and we left it and we all went away and thought and ideas percolated through people's heads. It was a difficult process at the very start. People weren't used to discussing their religion, their faith their belief system their spirituality. . And that re-imagining the Catholic school process that we went through, we are probably only now seeing the ultimate workings out of that program.... I strongly believe that Catholic schools more than any, have that opportunity to engage with a strong faith based community that is secure in its own identity. I think that is very important. And I think that it became, again that word accelerant to propelling students towards their ultimate success....

How?

As a sink school, as a school that you would avoid sending your child to if you could, that you would do everything to try and get your child in somewhere else. Now I remember joining the staff here and thinking oh God, this school here what is it going to be like? I will give it two or three years here and then I'll get a job in another school and move on. And very quickly I started to find that supportive Catholic, family ethos that exists in St Isidore's...actually you were working in a school that was full of fantastic teachers,; a really, really supportive management and principal who were just doing their best. And bit by bit, year by year we chipped away at the primary schools and we tried to get them to believe in what we were doing and we started to succeed. More importantly we can provide an education where the most high calibre academic achiever can get four A' stars in their A' Levels here and go off and do the most fantastic degrees that they can do in any of the third level institutions that are around us.... plus children who have learning difficulties can be educated in our learning support centre together (Senior teacher, St Isidore)

Strike (1999) in his analysis of schools and communities has argued that 'constitutive values' are pivotal in the realisation of effective spaces for learning. Constitutive values are, he argues, the guiding beliefs that bond communities together. Thus he suggests that when schools are reconceptualised as 'communities organized around constitutive beliefs, they are less alienating places for learning. They can have a degree of moral as well as programmatic coherence that most public schools cannot. Their members can see themselves as engaged in a shared project to which they are committed, and they can be committed to one another for this reason' (1999:68). The data here similarly demonstrate the importance of shared values and such collective commitments: The work undertaken around the Catholic ethos appears to have re-energised participants' commitment to the Catholic mission of the school and reawakened a sense of community cohesiveness that teachers believed had been lost in the years prior to this process. What is perhaps most important though is that as the school has become more centred on its 'constitutive Catholic beliefs' it has also become more 'successful' (in so far as pupil academic performance is a measure of 'success'). Hence it might be argued then that when the values of Catholic education are shared and cohesive they will undergird the soul of the school and the 'hidden injuries of class' that Reay (2006) argues are perpetuated by contemporary educational policy may be mitigated as teachers will raise standards naturally through a deep commitment to the emotional and spiritual wellbeing of children. 


\section{$\underline{\text { Conclusion }}$}

The purpose of paper was to explore how Catholic schools interpret and uphold the Catholic ethos within an educational policy context which privileges managerialist values. Drawing on data from two Catholic schools the paper argues that despite evidence to suggest that managerialism and Catholic education are inherently oppositional tensions between the managerialist discourse and the Catholic ethos were not manifest in either context. Although the qualitative nature of the paper precludes generalisation it does nonetheless raise several issues that are worth further reflection:

Firstly, the paper has shed light on what it means to be a Catholic school in a polity that is dominated by managerialist values. In keeping with Church documentation/teaching both schools were broadly defined by their commitment to social justice and Catholic religiosity. However the data raises questions about the universality of the values modelled by the Catholic school. The dissection of social justice offered a complex picture of the lived reality of Catholic schools and shed light on the fundamental distinctions that can exist between schools in this sector: Where social justice was defined in terms of social inclusion, as in St Isidore's, the emphasis was on building the self-esteem and dignity of the deprived and excluded on the basis that this would improve academic performance. In this context the harsher realities of managerialism did not come to the fore as children appeared to be supported to realise their academic ambitions without forfeiting their sense of personal worth and emotional stability (Reay, 2006). Yet where social justice was defined in terms of social mobility and where the means of delivering this education was informed by managerialist notions of surveillance and regulation, as in St Scholasitca, the potential for children to realise their academic ambitions was clearly high but this was against a possible loss of esteem and confidence amongst those from disadvantaged backgrounds (Reay, 2006). Whilst further research is required, the data suggests the potential of Catholic schools which are market focused and business oriented to reinforce rather than challenge the injustices embedded in society.

Secondly, and relatedly, the paper suggests that despite the pervasiveness of neo-liberalist and managerialist approaches to education its effects can be moderated and tempered by Catholic schools. Managerialism will inevitably define the objectives and processes of the schools regardless of their value base, but, and as is evident above, those schools with a coherent and cohesive commitment to social inclusion may be able to mitigate its more corrosive effects. Whilst Strike (1999) argues that a strong 'constitutive value system', resonant of those embedded in some Catholic schools, is critical for the success of a school this paper suggests that such a value base might also guard against the emotionally and economically vulnerable within a results oriented, competitive educational culture; something that is perhaps particularly relevant for Catholic schools located in economically challenging contexts.

Finally, the data suggests the significance of constant reflexive dialogue for identifying the components of Catholic education and reinforcing the values embedded in it. The data from St Isidore's reveals that reflective engagement around the core mission of Catholic education had led to a spiritual renewal and a reinvigoration of the professionals' commitment to building an inclusive, socially just society. Without this and by one teacher's admission, the school would have been failing in its obligations towards the marginalised and the excluded; yet it is these obligations that lie at the heart of Catholic education and they serve to remind that the acquisition of knowledge and skills is the means and not the end goal of education (Grace, 2002).

\section{$\underline{\text { References }}$}


Ball. S., Bowe, R. and Gewirtz, S. (1994) 'Schools in the market place: an analysis of local market relations', in W. Bartlett, C. Popper, D. Wilson and Le J. Grand (eds) Quasi-markets in the Welfare State: The Emerging Findings, p 78-94Bristol: SAUS Publications.

Ball. S.J. (2003) 'The Teachers' Soul and the Terrors of Performativity', Journal of Education Policy )18(2): 215-228.

Considine, M. (1988) 'The corporate management framework as administrative science; a critique.' Australian Journal of Public Administration 37(1): 4-18.

Flick, U. (2013) The SAGE Handbook of Qualitative Data Analysis, London: SAGE

Gewirtz, S., Ball, S.J. and Bowe, R. (1993) 'Values and Ethics in the Education Market Place: the case of Northwark Park ', International Studies in Sociology of Education, 3(2): 233-254

Grace, G. (2002). Catholic Schools, Mission, Morality and Markets. Routledge Falmer: London.

Jeffrey, B. and Woods, P. (1998) Testing Teachers: the effect of school inspections on primary teachers (London: Falmer Press). Lauder, Hugh and Hughes, David (eds) (1999) Trading in Futures, Why Markets in Education Don't Work, Open University Press: Buckingham.

Lauder H, Hughes D, et al. (1999) Trading in Futures: Why Markets in Education Don't Work.

Buckingham: Open University Pres

Lynch, K (2013: 5) New Managerialism, Neoliberalism and Ranking Ethics In Science and Environmental Politics Vol. 13: pp1-13

McKeown, D. and Clarke, J (2006) CCMS: Policy And Influence - A Model For Progress in Caitlin Donnelly, Penny McKeown and Robert Osborne (Eds)Devolution and Pluralism in Education in Northern Ireland; Manchester University Press pp.260-268

McLaughlin, T.H. (1994) 'Politics, Markets and Schools: The Central Issues' in Bridges, D and McLaughlin, T. (eds) Education and the Marketplace, London: Falmer House, pp. 153-168.

MacFarlene, B. (2013), 'The Surveillance of Learning: A Critical Analysis of University Attendance Policies, Higher Education Quarterly, 63(4): 358-373

Mercer, J. (2007) The challenges of insider research in educational institutions: wielding a double-edged sword and resolving delicate dilemmas Oxford Review of Education, 33(1): 1-17

Olssen, M., Codd, J., and O'Neill, A. (2004) Education Policy, Globalization, Citizenship and Democracy, Sage:

London

Pring, R. (1996), 'Markets Education and Catholic Schools' in McLaughlin, T, O'Keefe, J. O'Keefe, B (eds) The Contemporary Catholic school, Context, Identity and Diversity, London: Falmer Press .

Reay, D. (2006) 'The Zombie Stalking English Schools, social Class and Inequality', British Journal of Educational Studies, 54(3): 288-307

Rutherford, M. B. ( 2011 ). The social value of self-esteem. Social Science and Public Policy 48 , $407-412$

Smith, A. ,Montgomery, A. (1997) Values in Education in Northern Ireland. Belfast: Council for Curriculum, Examinations and Assessment (CCEA).

Strike, A. (1999) Can Schools be Communities? The tension between shared values and Inclusion, Educational Administration Quarterly, 35(1): 46-70

Verhaeghe, P.(2014) 'Neoliberalism has brought out the worst in us' The Guardian Online, http://www.theguardian.com/commentisfree/2014/sep/29/neoliberalism-economic-system-ethics-

personality-psychopathicsthic Accessed 10/11/2016 
$12 \mid \mathrm{P}$ a g e 